\title{
Ecstasy and Vision
}

\author{
By ANDERS HULTGÅRD
}

In this paper we shall present some observations on the role played by ecstasy in the activity of the seer, as he emerges in ancient Jewish and Iranian texts.

\section{Ancient Judaism}

In the Jewish religious literature of the Hellenistic-Roman period visions are described on almost every page, and visions were the most important means of divine revelation. Here we are immediately confronted with an essential problem. Do these descriptions reflect genuine visionary experiences or is the vision form to be interpreted as a mere literary convention? The problem has often been discussed (e.g. Lindblom 1963, 122-148; Russell 1964, 158-172; Niditch 1980, 158), but no definite solutions have been presented, the main reason being the material itself: a body of texts produced about two thousand years ago, composed, transmitted and reworked in a milieu of which our knowledge is incomplete. The fact that visions were widespread and popular in the ancient cultures of the Mediterranean area and the Near East strongly suggests their conventional use. A critical analysis of many vision texts underlines their traditional and literary character. However, it would be rash to deny that genuine visionary experiences could occur among the circles which produced the apocalyptic writings. The growth and spread of Jewish vision literature would be inexplicable if there were not real visionary experiences at its core. There is therefore some justification in scrutinizing the texts in order to find evidence reflecting the seer's genuine experiences.

In the Jewish texts of the Hellenistic and early Roman period, we do not find any coherent and detailed description of the circumstances under which the seer receives his vision. What we have are allusions and short, sometimes isolated, remarks but, taken together, these indicate an underlying context in which ecstatic experiences seemed to accompany the visions. A pattern may be discerned for the circumstances leading up to the vision itself:

1. There is first a crisis situation (cf. also Niditch 1980, 159) which strongly affects the seer and which manifests itself in grief, lamentation, anxiety and 
brooding. The crisis may concern the nation or the community, mankind in general or particular groups within the society. To illustrate this aspect of the pattern, I give some examples:

\section{crisis situation}

Daniel 7-10

IV Ezra and II Baruch
The persecution of the Jews under Antiochus IV Epiphanes.

The catastrophy of A.D. 70: destruction of Jerusalem and the Temple. seer's emotional manifestations

"I mourned for three whole weeks" (10:2).

"I fasted with tears and lamentations" (IV Ezra $5: 20-21$ ).

"I wept over Zion and lamented over the captivity which threatened the people" (II Bar. 6:2).

not explicitly mentioned.

I Enoch 14-15 The judgment on the fallen angels and the sons of men.

Testament of The increasing lawlessness Levi 2-8
"I was grieving for the race of the sons of men" (2:4).

2. Secondly, before receiving the vision, it is often stated that the seer goes away to a lonely or deserted place, in nature or elsewhere. He secludes himself from his normal environment:

Daniel 10:4 "I found myself on the bank of the great river, that is the Tigris" (cf. also 8: 2).

I Enoch 13:7 "I went away and sat down at the waters of Dan, in the land of Dan, which is to the south of the Hermon mountains, on their west side."

Test. Levi 2:3 "And when I was feeding the flocks in Abel-Maul."

IV Ezra 9:24 "Do not fast this time, but go to a flowery field where no house and 26 stands ... So I went out, as the angel told me, to a field called Ardat" (cf. also 14:1 and 14:37).

II Baruch 21:1 "I went out from there and sat down in the valley of Cedron in a cave of the earth. There I sanctified myself ..." (cf. also 35: 1 where Baruch sits down on the ruins of the holy place).

3. Thirdly, in some vision texts it is emphasized that the seer receives "understanding"' before the vision is granted to him. In other words, he has gained an insight into the causes of the crisis situation:

Test. Levi 2:3 "The spirit of understanding of the Lord came upon me and I saw all men corrupting their way." 
IV Ezra 5:22 "And my soul received the spirit of understanding."

4. Fasting and other forms of ascetic practice, purifications and prayer seem necessary to receive visions:

Daniel 10:2-3 "I refrained from all choice food, no meat or wine passed my lips, and I did not anoint myself until the three weeks had gone by."

I Enoch 13:7 "I read the account of their petitions aloud" (perhaps a repetitive, chant-like reading as Niditch 1980,160 suggests).

Test. Levi 2:4 "And I prayed to the Lord that I might be saved."

IV Ezra 9:24-25 "Go to a flowery field where no house stands, and eat only what grows there - no meat or wine-and pray unceasingly to the Most High"' (cf. also 12:1).

5:13 "But turn again to prayer, continue to weep and fast for seven days" (cf. also 5:20, 6:31 and 35).

II Baruch 21:5 "Go and purify yourself for seven days and do not eat bread, do not drink water and do not speak to anyone" (so also 21: 1).

47:2- " "When I arrived there, I sat down and fasted for seven days ...

48: 1- and after the seventh day I prayed thus to the Most High".

The points mentioned above may be seen as inducing a state of heightened consciousness and of ritual purity, which prepares the seer for receiving the vision. They also favour the transition to the final state, during which he sees what is hidden from ordinary men. This state of mind may be called ecstasy, although the Jewish texts are very reticent on such matters. There are however indications suggesting real ecstatic experiences similar to those of the shaman, the prophet and other types of religious authority in which ecstasy plays a prominent part.

The beginning of a vision is frequently announced by the indication that sleep overcomes the seer. It may of course be explained by the fact that many visions are thought to occur in the form of dreams seen in the night during the normal sleep. There remain, however, a number of instances where this explanation is less plausible. The introduction to the visions in the Testament of Levi describes the patriarch feeding the flocks when understanding from the Lord comes upon him (2:3). Having finished his prayer (2:4), he then experiences that "there fell upon me a sleep and I beheld ..." (2:5). Here the mention of a sudden sleep appears to be quite unexpected, but if interpreted as an ecstatic trance, the reference becomes well-integrated into its context. Other similar cases are found in I Enoch 13:8 and II Baruch 52:8-53:1.

In addition to the metaphors "sleep" and "fall asleep" to describe the ecstasy of the seer, we find other formulations indicating the state during 
which the visions are provided. The Book of Daniel 10:5-10 describes the initial stage of a vision. Confronted with the flaming appearance of the angel, Daniel's strength leaves him (v. 8) and he falls "prone to the ground in a trance"' (v. 9 hayiti nirdām; the latter word is rendered by katanenygmenos in Theodotion). ${ }^{1}$ The present structure of the text intends to convey the idea that the seer's reactions are caused by the awe-inspiring appearance of the angel. They may however be interpreted as hints of ecstatic experiences, obscured or given a different context in the literary redaction(s) of the vision. The mention in II Baruch 6: 3 of "a powerful spirit" (in Syriac: $\left.r w h^{2} d h y l^{\prime}\right)$ which lifts the seer upwards is best explained as an expression of ecstasy (see also I Enoch 71: 1). The important passage in I Enoch chapter 14 records a heavenly tour of the seer to behold the glorious dwelling-place of Yahwe and to receive divine revelation. In this chapter we find an interesting passage (vv. 8-9) describing what may be a reminiscence of genuine ecstatic experiences:

"Behold, clouds in the vision called me and mists summoned me, and the stars in their courses and lightnings hastened me and excited me, and winds in my vision caused me to fly and lifted me upward."

There are two passages in IV Ezra (6:36 and 9:27-28) where, immediately after the preparatory pattern, we find the remark that the "heart"2 of the seer was "agitated" or "excited" (Latin text: turbabatur, Syriac text: $m \check{\operatorname{tg}} \check{s} h w^{\prime}$ ) followed by a direct contact with the divine: "and I began to speak in the presence of the Most High." These formulations can be interpreted as allusions to the ecstasy of the seer.

Indications of faintness, agony and similar phenomena are not infrequently found in connection with the visions. The authors and redactors of the texts often have them appear as the seer's reactions to what is seen. The content of the vision is so overwhelming that the seer's strength fails him, he trembles and is overcome by agony (e.g. Daniel 8:27 and I Enoch $60: 1-4) .^{3}$ It is possible that these descriptions of faintness and agony originally had a different context, being expressions of the ecstatic state in which the vision was received. This becomes more evident in other cases, e.g. Daniel 10:8, IV Ezra 5:14 and 12:3. In the two latter passages, we find indications of the seer's physical state when awakening from the vision

\footnotetext{
${ }^{1}$ A similar reaction is described in 8:18: "When he (sc. the angel) spoke to me, I fell to the ground in a trance."

2 The word "heart" in these passages reflects a semitic form of expression and should more rightly be translated by "mind".
}

${ }^{3}$ In IV Ezra 6:37 we find an additional remark which probably indicates visionary ecstasy: "with spirit aflame and in great agony of mind I said.", 
itself. So it is said in 5:14: "I awoke with a start, shuddering, my spirit faltered, and I was near to fainting." Such a description is so true psychologically that it is difficult not to see a reflexion of genuine ecstatic experiences.

\section{Ancient Iranian religion}

The vision as a primary means of conveying divine revelation also appears in Zoroastrianism and does so with the founder himself, Zoroaster. Although the main source, the Gathas, presents only allusions to Zoroaster's role as a seer, it seems clear that he may be described as a kind of ecstatic visionary. ${ }^{4}$ Explicit evidence of visions and their function of granting divine revelations is found in the Middle Iranian texts.

The Bahman Yašt, a compilation of diverse apocalyptic materials, records two versions of a dream-vision (I, 1-11 and $\mathbb{I I}, 1-29$; edition of Anklesaria 1957) received by Zoroaster. The interesting point in these texts is the intimate relation between ecstasy and the divine knowledge granted to the seer. We also catch a glimpse of the particular technique used for provoking the visionary ecstasy.

Before having the vision, Zoroaster is given a cup of water by Ahura Mazda. While drinking it, Zoroaster receives the divine quality of visionary knowledge:

"And Zoroaster drank from it and he (sc. Ahura Mazda) intermingled the wisdom of omniscience with Zoroaster. Seven days and nights Zoroaster was in the wisdom of Ahura Mazda."' (III, 7-8)

The words "wisdom of omniscience"' (Pahlavi: xrat $\bar{\imath}$ harvisp-ākāhīh) seem to be a technical term indicating the seer's gift of divine vision. The text immediately continues: "and Zoroaster saw ...' followed by the description of the things seen. I have elsewhere (Hultgård 1982, 101-111) illustrated what the Iranian tradition meant by omniscient wisdom. Let me here add some remarks on the ecstatic character of Zoroaster's visions.

The trance state during which the vision is given is described as a sleep. In I, 5 it is said: "When he arose from the sleep . .." and III, 12-13 records something of the seer's physical and emotional experience when awaking from the ecstasy:

"Zoroaster reflected that he had seen (it) in a pleasant sleep granted by Ahura Mazda: 'I am not restored from the sleep', and he took both hands, rubbed his own body: 'I have slept a long time and I am not restored from the pleasant sleep, granted by Ahura Mazda',".

4 The character of Zoroaster as an ecstatic visionary has rightly been emphazised by
Nyberg 1938, 146-187 and Widengren 1968, $86-93$. 
The manner in which Zoroaster enters into the visionary state is only hinted at, but another tradition recording visionary experiences gives more information. This tradition which is found in Dēnkart VII, 4:84-86 and Pahlavi Rivāyāt XLVII, 27-32 describes the heavenly journey of Vištāspa, model of piety and justice in the Zoroastrian religion. Before undertaking his visionary tour, Vištāspa is visited by a heavenly messenger who urges him to drink a cup of haoma (or wine, according to Pahl. Riv.) mixed with hemp or henbane (mang). He then falls into a deep sleep and his soul is taken to heaven. There he sees things which persuade him to adopt the Zoroastrian faith. The use of a specific beverage to produce a visionary ecstasy is here clearly alluded to and makes it probable that the water mentioned in Bahman Yašt represents a later correction due to the redactor's negative attitude towards this technique of provoking the ecstasy (cf. also Widengren 1968, 91). Vištāspa is however not a divine revealer like Zoroaster and this may be the reason why the conveyance of "omniscient wisdom" is not applied to the figure of Vištāspa.

The Book of Artāy Virāz describing the journey of the pious Virāz to heaven and hell is certainly the most spectacular vision text of ancient Iran composed in the Sasanian period. For our purpose, the introductive part (chapters I-III) is particularly important as it shows us how the ecstatic vision was produced. In addition to the consumption of a specific beverage, prepared from wine and hemp (mad ut mang, II, 22 and 29-31; cf. also I, 38 ), we also find some sort of preparatory pattern. First, a special place is selected, presumably in a fire-temple, and the seer undergoes a ritual purification: "and Virāz washed his head and body, and put on new clothes" (II, 25). He then performs the ceremony of the consecrated bread (drōn), remembers the departed souls and eats food (II, 28). Three golden cups filled with wine and mang are given to Virāz in a ritual manner. The text goes on: "He consumed the wine and the mang, and said grace whilst conscious and fell asleep on the cover'" (II, 31). The summary of the seer's journey given in III, $1-4$ is worth quoting:

"And the soul of Virāz went from the body to the peak of Daiti, ${ }^{5}$ (over) the Čnvat bridge and came back the seventh day and night (haftom rōó šapann) and went into the body. Virāz rose up as if he arose from a pleasant sleep, thinking of Vohu Manah and joyful."

Some points should be commented on. Although the Book of Artāy Virāz represents a later stage in the development of Iranian vision texts, it draws

${ }^{5}$ According to Bundahišn IX, 9, the peak of the Daiti mountain is in the middle of the world and it is from there that the Cinvat bridge begins. 
on earlier traditions similar to those found in Dēnkart VII and Bahman Yašt, which have an Avestan background. The term xvamn i xvaš "pleasant sleep" in Artāy Virāz III, 3 to indicate the trance state appears in Bahman Yašt III, 12-13 as we have seen above. The period during which the ecstatic vision lasts, comprises seven days and nights (haft rō̌c šapān; Bahman Yašt III, 8 and Artāy Viräz III, 2). It is noteworthy that the mang mentioned in Artāy Virāz II, 29 is qualified as that of Vištāspa, an allusion to the tradition underlying Dénkart VII, 4:84-86. The words "thinking of Vohu Manah", (Vahuman mènišn) recall the role played by this divine figure in accompanying the seer to the heavenly world (see Yasna 51:16, Dénkart VII, 3: 51-62 and Zätspram XXI).

\section{Concluding remarks}

The Iranian material shows clearly the importance of ecstasy in the activity of the seer. The ecstatic seeing also means that the visionary shares with Ahura Mazda a divine quality, the "wisdom of omniscience". This feature is clearly expressed with regard to Zoroaster, ${ }^{6}$ but it is not evident in the visions of Vištāspa, whose role as a seer seems to have been a more passive one. ${ }^{7}$ The granting of the "wisdom of omniscience" appears as a temporary gift (for the details see Hultgård 1982,111) and it conveys to the visionary a supernatural seeing. The technique of consuming a beverage to which some kind of narcotic (mang) has been added, appears to be a typical feature of the Middle Iranian vision texts. It would however be wrong to conclude that this was the only technique applied by the Iranian seers. Other means of provoking religious ecstasy were certainly in use. There is evidence to suggest that chanting was an important method of inducing ecstasy within the early Zoroastrian community (cf. Nyberg 1928, 160-163 and Widengren 1968, 92-93).

Specific techniques for inducing the ecstatic state are not recorded in the Jewish sources. Some elements in the pattern leading up to the vision may be interpreted as parts of a method for inducing the final ecstasy, i.e. fasting and prayer; the latter is sometimes described as quite exhaustive, e.g. Baruch 21:26). We do not find in the Jewish material a clear correspondence to the Iranian notion of "omniscient wisdom". The closest examples would be Daniel 10:1 and IV Ezra 14:37-40. In the former passage it is stated that "understanding" ( bināh) came to the seer "in the course of the vision'. In IV Ezra 14:37-40 we have an interesting parallel to the drinking

6 The quality of "omniscient wisdom" is also ascribed to the figure of J̆āmăspa, who is, however, not explicitly described as a visionary, cf. Hultgård 1980, 111.
7 In this respect, Vištāspa conforms very well to the typology of the seer as elaborated by Wach 1944, 351-353. 
of the ecstatic cup and the conveyance of the "omniscient wisdom" as recorded in the Iranian texts. The passage is worth quoting in full: "I took with me the five men as I had been told, and we went away to the field, and there we stayed. On the next day I heard a voice calling me, which said: 'Ezra, open your mouth and drink what I give you.' So I opened my mouth, and was handed a cup full of what seemed like water, except that its colour was the colour of fire. I took it and drank, and as soon as I had done so my mind began to pour forth a flood of understanding, and wisdom grew greater and greater within me, for I retained my memory unimpaired".

The context reveals that the passage cited is intended to show how Ezra was able to dictate to the five men the whole revelation given to him by God, but it will certainly also convey an idea of how divine inspiration was thought to be transmitted to the seer. The procedure described looks like a symbolic act, similar to those described with regard to several Old Testament prophets, and performed to illustrate how the seer is inspired with the holy spirit (note the wording "colour of fire"!). It is however possible that we are dealing with an original technique of inducing the ecstatic vision which has been reinterpreted and changed into a symbolic act by the author or the redactors of the Ezra-apocalypse.

\section{References:}

Anklesaria, B. T. 1957. Zand $i$ Vôhuman Yasn with text, transliteration, and translation in English. Bombay.

Hultgård, A. 1982. Forms and Origins of Iranian Apocalypticism. Die Apokalyptik im Mittelmeerraum und im Vorderen Orient, hrsg. von D. Hellholm. Tübingen.

Lindblom, J. 1963. Prophecy in ancient Israel. Oxford.

Niditch, S. 1980. The visionary. Ideal figures in ancient Judaism, ed. by G. Nickelsburg and J. J. Collins. Michigan.

Nyberg, H. S. 1938. Die Religionen des Alten Iran. Leipzig.

Russell, D. S. 1964. The method and message of Jewish apocalyptic 200 B.C.-A.D. 100. London.

Wach, J. 1944. Sociology of religion. Chicago.

Widengren, G. 1968. Les religions de l'Iran. Paris. 